into the circulation, sensitized the tissues and produced the plienomena deseribed.

1)r. Frank E. Simpson, Clicago: The relation of the gonococcus to this form of dermatitis is very interesting. 'The gonococei have been looked for in the lesions very often, but have never been found, which, perlatps, is simply due to the fact that they were not looked for at the proper time. If they should be found eventually it would tend to uploold the contention that all the parakeratoses are due to a microbic agent.

\section{APPENDICITIS COMPLICATING PREGNANCY}

J'ALMJER FJNDLTYY, M.D.

Professor of Gynecology, College of Medicine, Univelsity of Nelsmskn

\section{OMAIIA}

It is my purpose to present briefty the debatable points of interest in relation to appendicitis as a complication of pregnancy, labor and the puerperium. Obstetricians were slow to appreciate the frequency and gravity of appendicitis as a complication of pregnancy. 'J'his was so because appendicitis was not clearly recognized until Fitz, in 1886, substituted the term ajpendicitis for typhlitis and perityphlitis. Eight years later, Paul 1s. Munde $^{1}$ reported three cases of appendicitis complicating pregnancy and two years later R. Llbrahams ${ }^{2}$ added twelve cases. The clinical deductions of Munde and Abrahams are generally accepted to-day. In fact there has been little of importance that lias been contributed by later writers. The most elaborate contribution to the subject is that of H. H. Schmid who collected 486 cases of appendicitis complicating pregnancy from the literature of the past twenty year's.

Appendicitis occurs with greatest frequency during the child-bearing period, hence it is not strange that it should be found to complicate pregnancy. But we are not to conclude that the combination is a coincidence in all cases. Nearly all authorities agree that a primary attack is not incited by the pregnant state but that there is a very great liability to recurrent attacks during pregnancy, labor and the puerperium.

As to the frequency with which women who lave suffered from one or more attacks of appendicitis prior to pregnancy experience a recurrent attack in event of pregnancy I quote the observations of Goedecke. ${ }^{3}$ He reported sixteen cases of pregnant women who lad suffered from an attack of appendicitis prior to their pregnancy and of this number five went through prernancy and puerperium with no trouble from their appendix, while eleven had a recurrent attack during their pregnancy.

The explamation for recurrent attacks in pregnancy, lies in the vascular engorgement of the appendix, in the constipation which is so commonly associated with pregnancy, in the toxemias of pregnancy, in the encroachment of the uterus in the carly montlis of pregnancy, and in the puerperium and, finally, in the ocea:ional presence of adhesions binding the appendix to the uterus and its appendages. While these factors doubtless tend to incite a recurrent attack of appendicitis they cannot be said to create a primary attack.

I am unable to arrive at any estimate of the frequency of the complication. 'lreves, in 1895, reported six cuses

* Iead In the section on Obstetrica und fynceology of the Amrerfean Medical Assuchation, at Its Sixty-Third Annual Sesslon, held th Atlantle City, Junc, $191 \%$

1. Munde, $\mathrm{I}^{2}$. IF. Med. Rec., New York, Dec. 1, 1804 ; Oct. 20, 1805: Mal'ch, 23 .

2. Abrthins: Ans. Jour. Obst., 1807, xxxv.

3. Goedecke: Zentialli. f. Gyuluk., 1912, No. 15. of appendicitis complicating pregnancy out of a total of 1,000 cases of appendicitis in women. Norris ${ }^{4}$ operated on 445 women of appendicitis, six of whom were pregnant. Sonnenburg performed 2,000 appendectomies, in four of which the appendicitis occurred in pregnancy and the puerperium. J3aldwin had six pregnancies in 1,800 appendectomies; Vineberg nine in 731 and v. Eiselberg thirtecn in 520. E. Fraenke $1^{5}$ found five cases in 40,000 pregnancies; Schauta four in 34,000; v. Rosthorn" two in 27,000 ; Fellner none in 4,000; v. Oordt four in 10,000 and Chrobak and v. Rosthorn thirteen in 13,000.

The gynecologist and obstetrician doultless find a much larger percentage of appendicitis complicating pregnancy for the very good reason that they sce more pregnancies and fewer cases of uncomplicated appendicitis.

$\Lambda$ ppendicitis emplicating pregnancy presents a serious problem because of the occasional difficultiss. encountered in making an carly clingnosis. It is true that both mild and severe attacks of appendicitis often go unrecognized in the course of pregnancy, in labor and in the puerperium. Mild attacks are interpreted as the ordinary discomforts of pregnancy and the severe cases occurring in the puerperium are frequently regarded as types of puerperal sepsis. Again, we find these attacks interpreted as intestimal colic, renal colic, mreteropyelitis, threatened miscarriage, salpingitis and tubal pregnancy.

While mild attacks do not alter the course of pregnancy, ecvere attacks will usually result in the interluption of pregnancy, and not infrequently in the death of the fetus in utero. The infection may extend to the rtterus by way of the fallopian tubes or by way of the lroad liguments and uterine wall to the placenta. In this manner, the colon bacillus has been conveyed to the placenta and fetus. The large percentage of fetul mortality observed in the reports of cases is due in part to the interruption of pregnancy prior to the period of viability and in part to fetal toxcmia. In eighty-nine appendectcmics on perforated appendices there were thirty-three abortions alter operation. In fifty non-perforated cases scven abortions followed operntion. Boije referred to eighteen cuses in Engstrom's clinic in which pregnaney was not interrupted. A gingrenous appendix with goneral peritonitis was operated on in the fourth month of pregnatney by 'T. K. Holmes ${ }^{8}$ and pregnnncy went to term with the delivery of a healthy child. Several such cases are on record.

Falk drained an appendiceal abscess containing two liters of pus without interrupting a six months' pregnancy. It is incumbent on the surgeon, therefore, to employ every possible means of preventing miscarriage after operating. When a viable fetus is born early in an attack the elanece for the lif'e of the child are not grently influenced by the appendiceal infection but when the delivery occurs late in the course of a severe attack of appendicitis the fetal mortality is great as the result of sepsis. It has been frequently observed that death of the mother rapidly follows the interruption of precunancy. While miscarriage is regarded as a contributing factor to the fatal issue, sepsis is the chief determining factor.

It is generally conceded that appendicitis complicat. ing pregnancy and the puerperium Juns a more rapil

4. Norris : Am. Gyn. nud Olsst. Jour., xiv, 425.

5. Fraenkel, L. : Samml, klin. Voltr., 1898, No, 229, s. p. 13335.

6. Von losthorn: Med. Klln., 19u7, s., b. 330

7. Bon llosthorn: Med. Klin, 19u7, S., p. 330. 1008 .

8. Holmes, '1. K.: Am. Jour. Surg. And Gynec., Felsuary, 190:: 0. Fialk, Otto: Zentralibl. f Gyulls., 1000, xl, s. p. 103. 
and destructive comrse than in the non-gravid state. It is true that appendiceal abscesses are particularly liable to rupture into the free peritoneal cavity. 'Jhe explanation lies in the fact that the growing uterus of pregnancy and the eontracting uterus of labor and the puerperium f'orm the inner boundary of the alssess, hence the great liability of the alsseess to rupture.

Myers ${ }^{30}$ reported nine cases of appendicenl absecsses with three deaths from general peritonitis, and again Mevers collected the records of sixty-nine anses of appendicitis in which the patient was operated on in the course of pregnancy. Of these pationts forty-nine ( 71 per eent.) developed a gangrenous appendix with abscess formation. liabler"11 collected 235 'asus of appendicitis complienting pregnancy and the puerperium. In a total of 207 cases the appendix perforated in 103 ; eighty-nine patients were operated on with thirty-six maternal deaths. In fourteen of the perforated cases no operation was done; all the patients.tied. There were filty nonperforated cases in which operation was done with one maternal death. 'Twenty-eight cases oceurred in the puerperium, eighteen were perforated, in twelve the patients were operated on with four maternal deaths. 'J'wo of the five patients not operated on recovered after' rupture of the abscess into the rectum. In all of the non-perfornted cases oecurring in the puerperium the pationts recovered. Babler very pertinently concludes: "I'The mortality of appendicitis complicating pregnancy is the mortality of delay."

The evidence is convincing that appendicitis runs a more rapid and destructive course when complicating pregnancy and the puerperium and therefore demands prompt consideration at the hands of the surgeon.

If it be true that appendicitis is particularly liable to reeur in event of pregnancy it follows that women in the child-bearing period who have suffered one or more nttacks of appendicitis present a very special indication for the removal of the appendix.

I would not go so far as does Fraenkel ${ }^{\infty}$ in advising the removal of the appendix in all attacks, both mild and severe, oceurring in the course of pregnnney. When the attack is mild, unless oft repeated, it would secm advisable to postpone operntion until the end of the pucrperium. When there is a definite pronounced attack in the course of pregnancy or the puerperinm the demand for immediate operation is imperative in view of a possible rapid and destructive conrse. 'The enrlier in the course of both pregnancy and appendicitis the operation is performed the better will be the result. When an appendicenl abseess is recognized drainage should be established without delay because of the great liability of rupture of the abscess into the peritoneal cavity. 'This applies as well to abscess formation at the beginning of labor when the contracting uterus would be so liable to disseminate the pus. 'I'he greatest caution must be exereised to prevent the contamination of the genital tract by the escaping pus.

It is seldom that pregnancy is interrupted in the course of a mild attack of nppendicitis but it is the rule that pregnancy is interrupted in the course of severe attacks. When operation is performed in such cases, every preention should be taken to prevent miscarringe. In operating the uteris should be carefully gunded from undue handling and exposure and after operation opiates shonld be administered to the patient and absolute rest enjoined.

10. Myers, Max : Am. Jour. Olst, March, 1006, p. 358

11. Bable1: The Jou Nol, A. M. A., Oct. 17, 1008, p. 1310
In severe attacks occurring at the end of pregnancy and withont evident abscess formation, the rule should be to induce labor and to remove the apjendix at the completion of labor.

In the past six years I have had fifteen enses of appendicitis associated with pregnancy, labor and the pherperium. 'The first seven of these enses were reported in the American Jonmal of Obstetries;" the others ane given here:

Gass 8.-3rrs. 11, agred 32, quatipara, hand a severe attack of appendicitis two years before the pressent attack and had since sulfered from tenderness and pain in the appendiceal regron with gastro-intestinal disturbanees. ller fifth ehild wis born at torm, Murch 2, 1911, nul six hours after the completion of labor the temperature renched 101.5 $\mathrm{k}$.: in forty-eight hours it was $105.6 \mathrm{l}$., and the pulse was 120 . There was intemse puin in the region of the appendix, rapicl listention of the ablomen, nuusea, obstipation and muscular rigidity over the right lower quadrant. I first saw her at the end of the third day of the puerperimm and operated willin two hours. The appendix was not adherent but was lurge, congested aul contained a small amount of pus. Recovery followel.

Cass 9.-Mrs. S., aged 22, secumdipurn, first compluined of pain in the region of the appendix three penrs before. In these thre yeurs she had had several moderately seme nttucks of appendicitis; the last was not severe but her physician alvised the removal of the appendix in view of the fact that she was agrin pregnant. I operated on hor in the fifth month of gestition. The appendix was thickened, but contuined no pus und no allesions existed. Recovery followed und the pregmusy proceded to term with the delivery of a lrouthy child.

CAsE 10.-Mrs. W., aged 28, primipara, entered the hosp,ital in the twelfth woek of gestation. Five yenrs previously, she land her first attack of appendicitis. Since then she had had several recurrent altucks of moderate severity; the last was in the fifth week of her present pregnaney. These nttucks were of modernte severity. She suffered from the usual gastro-intestimal disturbances of chronic nppendicitis, nud the pain in the right iline region hand been stendily increasing as the presunney alvaneed. I removed a thickened non-sdlicrent appendix. Recovery followed without the interruption of preguancy.

Case 11.-Mrs. S., nged 22, primipara, was about ten weoks pregmut when she experienced her second attack of append. citis, the first linving oceured six months bofore. I operated ou her a few days after the acute symptoms of the second nttuck had subsided and removed a thiekened. congested appendix which was not adherent and did not contuin pus. lecovery followed and the pregnaney procosded to term with dolivery of a lientily buby.

Cask 12.-Mrs, la, aged 31, primiparn, hal never expori. enced an nttuek of appendicitis until leer present prenguney. One week before admission to the hospital she had a moderately severe attack. The appendix was removed in the ninth week of gestntion; it was in the subacute stage of $a$ catarlial inflammation. Recovery followed. The pregnuney procended to term.

Case 13.-Mrs, K., aged 24, mullipara, misencried at the seventh month of gestation. She experieneed great pain in the region of the appendix throughout labor. I saw her three weeks after the miscurriage when f drained an apperedieenl abserse throngh the right lateral incision. The nberess rontuined fully two quarts of pus. The records were not kept for the first three weeks following the miscurriage, but it was stated by her plyysician that her temperature was elevated to $101 \mathrm{l}$. by the end of labor and ranged from $101 \mathrm{H}$. to $105 \mathrm{f}$. to the time of operation. So far as known, this whs her first severe attack, but there were several preceding milal attacks. Recovery followed.

Casb 14.-Mrs. S., nged 29, secundiparn, referred to mo by br. Peters of Stanton, Neb., was then believed to be about

12. Am. Jour. Obst., 1900, ]v, 0. 
three weeks pregnant. Two days after her first confinement she experienced her flrst attuck of appendicitis which was - moderately severe. This was three and one-half year's ago. Since then, slie has had more or less discomfort in the neigh. borlood of the appendix. In her second pregnancy this dis. comfort was increased. She gave birth to her second child eighteen monthes ago. For two or three dnys preceding labor and for a week following labor, the pain in the right side was very intense. The abdomen becume distended, there way elevation of temperature and the bowels wore moved with great difficulty. She continued to suffer from pain in the right side to the time of operation. I. removed an appendix which was distended throughout its entire course with bloody feces; there were no adhesions. Recovery ensued without miscarriage.

Case 15.-Mr's. B., nged 24, primipara, referred by Dr. Sulli. ran of St. Edward, Neb., is in the seventh month of gesta. tion. She has had four severe attacks of appendicitis-the? first eighteen months ago, the second one yenr ago, the thirl three months ago, when she was about four months pregneut and the last one week ago. All these attacks were typienl and severe. At no time sinee her first attack has she been free from discomfort referable to the appendix. Her last attack has completely subsided, leaving nothing but some localized tenderness. In the coflort to save the child $I$ am keeping lier under observation in the hospital and should another attack set in slie will be operated on without delay.

\section{CONCLUSIONS}

These fifteen cases present several points of interest:

1. In all but one of the fifteen cases there had been previous attacks of appendicitis.

2. Six of the cases were mild attacks, in which all the patients recovered without the interruption of pregnancy. T'en were severe attacks in which seven patients recovered and three died. In all there were three deaths in fifteen cases and in one of the fatal cases the paticnt was not operated on.

3. In the fifteen cases the attacks oreurred in liabor in one, in the puerperium in five, and in pregnancy in nine cases.

4. 'The five cases occurring in the puerperium were of unusual severity.

5. Of the fifteen cases two patients died of septic peritonitis and one of bronchopneumonia. One of these patients was not operated on.

6. In the majority of cases the attacks recurred in the carly months of pregnancy.

7. Mild attacks showed no disposition to disturb the pregnancy.

8. In Case 15, the patient refused operation in a severe attack which occurred in the third month of gestation. She had recovered from her last attack before entering the hospital and inasmuch as she was in her seventh month of pregnancy it was thought advisable to delay operative interference in the interest of the child, but with the understanding. that she would be operated on at the onset of a subsequent attuck.

9. In Cases 4 and $6^{11}$ the fetus was dead in utero, the latter at term, the former in the early weeks of its development.

10. In Cases 2 and $6^{11}$ there was a gangrenous appendix with abscess formation which rapidly spread to the general peritoneal cavity and resulted fatally.

11. In no instance was pregnancy interrupted after the removal of the appendix.

12. These experiences lead me to the conclusion that pregnancy probably has no influence in creating a primary attack of appendicitis but has a very great influence in creating renewo attacks.
13. Of women who have had appendicitis prior to pregnancy 50 to 60 per cent. will suffer more or less disturbances referable to the appendix in subsequent pregnancies.

14. Inasmuch as appendicitis complicating pregnancy and the puerperium tends to r'un a rapid and destructive course, it is particularly hazardous to delay operative interference in sharp attacks.

15. The carlier in the attack and the earlier in the course of preguancy the operation is performed, the better will be the results.

16. Wagner estimates the mortality of non-operative scvere cases at 77 per cent. as contrasted with a mortality of 6.7 per cent. in cases of all grades of severity in which operation is done within the first forty-eight liours, a record that is not exceeded in operating appendicitis that is not complicated by pregnancy. Doubtless this record of 6.7 per cent. maternal mortality in all cases in which operation is done within forty-eight hours from the beginning of the attack would be materially reduced were these patients operated on within the first twentyfoul hours.

3002 Jincoln Joulevard.

\section{ABSTRACT OF DISCUSSION}

Dr. Jonn B. MUnpriy, Cliengo: The mortality of appendieitis is enoimously greater tian the mortality of any other condition. What are the anatomie and the pathologic conditions that contribute to this morinlity? The anatomic conditions that contribute to the mortality are, as shown, the fact that as the uterus enlarges during pregnaney it removes from the appendix its natural protectors, the omentum and the intestine. There are two opportunitios for infection to ocenr: hematogenous conditions in the bladder and rectum, and it severe attack of appendicitis. In miscarriage or labor, infertive material is scattered all about. One focus of infection is close to the outlet of the pelvis; infection may oceur either through the bloorl-vessels or by direct transmission from the vagina. We must determine how to avoid these dangers. Dr. Findley emplasizes these two facts, that when the condition was diagnosed and remedied early, the mortality was practically nit; when the condition was dingnosed late and the endenvor to remedy it was also late, the mortulity was colossal. Therefore, we go back to the proposition: Can wo dingnose the condition early'? If we chan diagnose the condition enrly, what is the excuse for wating? We can diagnose the condition early even in the presence of pregnuncy. What are the conditions. that we bave to differentiate? Hemutogenons infections of the kidney; infection of the bladder; obstruction to the ureter. Lesions of the kidney ean ensily be diflerentinted from acute appendicitis, with and without pregnancy. The onset of pain is the sume in both. The reilexes are normal in both; lenkocytosis oceurs in both, pirt. ticularly in the metastatic variety of infection. You have, therefore, the principal symptoms, except the local manifestation, the same in both. One of the important points in the diflerentiation is the exclusion of kidney and gall-bladder infection. It is ensy to exclude gall-bladeler disense from infection of the appendix, but it is not always easy to exclule renal complications. You can do it, however, in all cases. You must resort to flat percussion. Have the patient sit ou the side of the bed and let the hands come elenr down, so 118 to force the kidney ligh up. Then place the lund over the left kidney and strike it with the closed fist. If there is un acute obstruction the patient will immediately spring up, and it may be all he cint do to keep from striking you. If there is any one thing that a man of experience has concluded, it is that lie does not know what is going to occur in the ten or twenty or forty hours following the onset of the nppendicitis. If you do not know what is going to buppen, what justifiention have you for taking the hazard which Dr. Findley hut accentuated? 